\title{
The Construction of Private Institutions' Double-Ability Teachers Based on Genetic Concept
}

\author{
Yingle Yao \\ School of Zhengzhou Industrial Technology, Institute of Information Engineering, Xinzheng, \\ Zhengzhou, Henan Province, China, 451150
}

390169913@qq.com

Keywords: Private Institutions; Genetic concept; Open and shared; Double-type teachers

\begin{abstract}
In the environment of college source of students shrinking, private colleges innovate the construction of Double-type teachers, improve the core competitiveness of private institutions of higher learning is imperative. In this paper, to improve the core competitiveness of private education as a starting point, Learning advanced experience of building double-ability teachers team from abroad, this paper introduce biological genetic concept, put forward a new standard of private institutions of higher learning characteristics of double-qualified teachers: Open and share ideas, explore a effective way of private universities distinctive double-qualified teachers team building.
\end{abstract}

\section{The Present Situation of the Development of Teachers' Team in Private Schools at Home and Abroad}

The Present Situation of the Development of Teachers in Private Schools in China. All along, private college teachers construction is the key to its development. Private colleges and universities have no experience, no two signs, we must rely on the quality of teaching to shape the word of mouth, to win a better living environment. The private school teachers as the main body of school teaching and research is to complete the teaching tasks and improve the quality of education determinants. National long-term education reform and development plan (2010-2020) Article XIV stressed: to strengthen the "double teacher" team of teachers. However, after more than ten years of construction, the construction of "double-qualified" teachers still has many problems in the construction of private colleges and universities. In recent ten years, the research papers on the construction of "double-qualified" teachers in our country have been in progress. The research on the existing problems of the "double-qualified" teachers has also reached a consensus that the definition of "double-qualified" teachers is vague and the size of teachers Too small, unreasonable structure, teacher status and treatment is not high, a single source, training training model lag, the lack of scientific management mechanism, part-time teachers lack the relative stability.

The Present Situation of Teachers' Team Development in Foreign Private Schools. In the United States, teachers in higher education must have a bachelor degree or above, and have more than one year of relevant work experience and latest experience in teaching courses. In Germany, the requirements for teachers in colleges and universities are to obtain a doctorate degree and have at least 5 years of professional experience in the professional field. The basic requirement of the vocational and technical schools in Denmark is to complete the third level vocational education, have professional skills and have more than 5 years of practical work experience. Australia to university teachers to make the provisions of the qualifications, to obtain the appropriate qualifications, but also must have 5 years of business experience. Japan is responsible for the professional requirements of teachers in colleges and universities is required to obtain a master's degree, and in schools, research institutes, hospitals, factories engaged in professional courses related to research and technology-related business [3].

Throughout the history of world education, we found that the world in the process of training teachers have accumulated some experience, which is mainly reflected in: a clear goal of positioning, pay more attention to the cultivation of practical teachers; teacher access system 
standardization, teachers not only To meet the academic requirements, but also need to work in the enterprise for a certain period of time; in Germany teachers are national civil servants, teachers, high stability, teachers, the stability of reliable protection.

The Necessity of Constructing "Double - Qualified" Teachers in Private Schools. Under the environment of shrinking students, private colleges and universities will face fierce competition from domestic public institutions and overseas institutions of higher learning. Harvard University former principal Colonant once said: University of honor "is not its school and the number of people, and in its generation of teacher quality, a school to be tenable, teachers must have characteristics." Therefore, innovation It is very necessary to improve the core competitiveness of private institutions of higher learning.

In recent years, the rapid development of higher education in China, the existing nearly 9 million students, the higher education into the popular history of the stage played an important role. At the same time, private higher education institutions focus on the combination of work and study talent training mode and connotation development, vigorously carry out private higher education teaching reform, has made remarkable achievements. However, private higher education as a new type of higher education, its development in China only twenty years of history, but also because most of the private higher education institutions are upgraded from secondary specialized schools, in the school philosophy, system School management and other aspects of the prevalence of its scientific development problems. In the current and future for a long period of time, private institutions of higher learning will face from the domestic public institutions and overseas institutions of higher learning fierce competition. Therefore, how to accurately determine their own competitive advantage, and quickly enhance their core competitiveness, will become particularly important.

\section{The New Goal of "Double - qualified" Teachers in Private Colleges under the Concept of "Genetic Concept"}

The Profound Connotation and Extension of "Genetic Philosophy". Biological inheritance refers to the transmission of genes, so that offspring get the characteristics of the family. The bees dancing all day, collecting pollen, and making honey even sweet. They are waxy, built into a neat, delicate housing, even the construction engineers are also amazed. This ability is inherited by the previous generation to the next generation. So that all creatures "born with" behavior, habits or function, are relying on inheritance and inheritance. In the folk flow of such a sentence: "melon melon, beans are beans." This sentence summarizes the full connotation of the genetic. In other words, everything in nature is to follow a certain law to reproduce the offspring.

Drawing on the biology of the concept of genetic selection, the genetic application in all areas of life, will have a huge social, cultural, environmental and other economic values, such as cultural heritage, five thousand years of civilization left us a valuable legacy; Such as the blue out of the blue, better than the blue; such as the software upgrade is inherited the essence of the original software, remove the dross, to adapt to the new requirements of the software version; these images depict the concept of genetic epitaxy, that is, on the basis of the original, Advanced, good quality, excluding the part of the development does not adapt to the times, innovative ideas, is the scientific inheritance of sustainable development.

A New Objective of "Double - qualified" Teachers in Private Colleges. The construction of "double teacher" teachers is the key to implement the mode of personnel training and the key to improve the quality of higher education teaching. To develop the planning and construction of teachers, increase the intensity of the construction of teachers, is one of the most basic infrastructure of the school.

Based on the advanced experience of the construction of double - qualified teachers in foreign countries, this paper introduces the biological concept of biology and puts forward a new standard of double - qualified teachers with private colleges and universities. And shared ideas, from generation to generation of the mentoring system, to explore a new era of private institutions of higher learning characteristics of the "double teacher" teacher team building an effective way.

The idea of running higher education is to cultivate the talents of applied talents, mainly to 
cultivate the technical application talents of production, construction, management and service. Therefore, from the training goal to the teaching content, from the teaching mode to the teaching staff, In the previous college, but not the simplification of undergraduate education. Therefore, private colleges and universities "double teacher" teachers to build a new goal: to engage in private higher education teachers, in addition to have good professional knowledge and educational skills, with strong practical guidance, but also requires teachers Has open and shared ideas: open is willing to study hard at the forefront of professional technology, rich in the spirit of reform and innovation, both engaged in teaching and engaged in scientific research "double teacher" teachers; sharing is not stingy their own experience, and everyone To share, grow together, and jointly improve, so that excellent teacher experience from generation to generation, and can be accumulated and continued.

\section{Exploring the Effective Ways of Constructing Double - qualified Teachers with Private Schools}

Strengthening the System Construction of "Double - qualified" Teachers. For the government and the state to give private schools more funding and policy support. The tension of running school has been an important "bottleneck" to restrict the development of colleges and universities, and also hinders the training process of teachers. Compared with the public schools, private schools because of their economic, geographical environment, social status and other factors in the school funding is very tense, the introduction of high-level talent and the existing teacher training funding is limited.

Not a certain amount of funding for security, it can not fundamentally optimize the teaching staff, improve the overall quality of the faculty. Therefore, it is very important to increase the investment in the construction of teachers in private colleges. Relevant departments should increase the provision of funds to support the efforts of schools, schools should also strive to create the conditions, through a variety of channels and ways to raise funds to arrange for the construction of teachers. So as to effectively guarantee and promote the private universities and even the whole country of the cause of a virtuous circle of higher education.

The establishment of "genetic" double teacher training mode. Drawing on the biology of the concept of merit, genetic application in the double teacher training model, will have a huge social, cultural, environmental and other economic value. Such as the improvement of teacher training methods, teachers who have participated in the training should be open and shared ideas, through the forum, the form of the report, the training experience, training insights and some professional cutting-edge knowledge and brother's management model and other Teachers to share, communicate and exchange, to grow and improve, so that the new era of new dual-level faculty with the development of the times self-renewal and self-innovation, from generation to generation, so that excellent teacher experience can be accumulated and continued;

In addition, research is the teacher's first productive force. From the perspective of the long-term development of private colleges, it is not enough to pay attention to the teaching task of teachers. Teachers are engaged in educational research activities. It is an important measure to improve the mode of professional survival and improve the level of education and teaching. It is an important means to produce teaching experience, Therefore, the teacher's research should be supported by the school-related system, the formation of the school's strong scientific research atmosphere, to enhance the core competitiveness of private schools is of great benefit.

In the Training of Teachers in the Double Division, Fully with the People of the Flexible Mechanism of Colleges and Universities. The biggest advantage of private colleges and universities lies in the flexibility and flexibility in the following: First, the diversification of teachers' sources, unlike the public institutions to limit the teaching staff to the education system, private colleges and universities to encourage engineers, project experienced engineering staff into the campus, For the students to pass more real, more image, more reference value of the front-line experience and experience to promote the school teachers to double-type transformation; the second is to establish an open system of teacher circulation, the introduction of competition mechanism, rewards and punishments, to achieve feelings Keep the people, keep the environment, rather than 
through the strict management of tied; three is mercy is to lift, boldly open the courage of young talent, without age, regulations and other factors.

Use Good Positive Incentives to Improve the "Double Teacher" Teacher Treatment. First of all, the school to profit, as long as not mainly used for personal distribution, it is not illegal; this is to improve the basis of teachers' wages and benefits. We can borrow foreign countries, Hong Kong and Taiwan successful practices, to encourage foreign enterprises to donate to private colleges and universities, the establishment of private schools to tilt the tax policy to improve the flow of funds in private colleges and universities. In addition, private colleges and universities should make full use of the great role of the market economy, and strive to expand students, increase school income. Second, the relevant departments of the relevant government departments according to the local public institutions and the actual situation of the provisions of the standard line of wages and benefits, requiring private colleges and universities must be in strict accordance with the provisions of the standard, to pay wages and benefits to teachers, to pay social co-ordination and medical insurance, Full-time teachers to provide a guarantee.

The Establishment of High Quality Teachers of Higher Education Training Base. Learn from the experience of the United Kingdom, school-enterprise cooperation model is the institutions of higher learning "double teacher" teacher training an important model. In China, school-enterprise cooperation model can be used professional teachers to the way the enterprise post [9]. Teachers to counterpart business enterprises, with the teaching of the problems and confusion to the production line, both familiar with the production process and operation of the process, to understand the latest technical information, but also the opportunity to consult the relevant technical staff to consult, open the theoretical perspective[10]. To improve teaching ability, it can lead teachers from a single teaching type to the "double teacher" talent change[11].

\section{Significance}

The construction of double-qualified faculty is the most important symbol of educational modernization. Henan private education, as a useful supplement to public education, conveys a large number of talents for the construction and development of the Central Plains Economic Zone, and will play a role in radiation and demonstration of neighboring provinces and cities To promote the modernization of education in other provinces and cities, and thus promote the modernization of the Central Plains Economic Zone, while continuing to accumulate experience, provide a demonstration, expand the opening to the outside world, the formation of "open and shared" as the core concept of double teacher Team training model, become the country's economic growth is an important growth pole, in support of the rise of the central, close East-West contact, serve the overall situation in the country play a greater role.

Under the concept of "double teacher", the construction of the "double teacher" team is the key to improve the teaching quality of the private colleges and universities. The research on the training of the "double teacher" teachers in the private colleges and universities in Henan province is carried out and the countermeasures are put forward. Education "double teacher" teacher construction work to provide case study results, in order to further develop the characteristics of private institutions to lay a solid foundation for the national higher education "double teacher" teacher training model and theoretical construction to provide practical support, with important The theoretical significance and practical significance.

\section{Conclusion}

This paper draws lessons from the advanced and successful experience at home and abroad, introduces the idea of inheritance, and makes a preliminary study on the effective path of the construction of the teaching staff in the private colleges and universities in the new period. In this paper, the construction of the contingent of colleges and universities, especially the private colleges and universities is an important and long-term work. But it is only one of the important factors to improve the core competitiveness of private colleges and universities. It should coordinate and 
develop with other factors and jointly promote the development of private colleges and universities, which needs further study.

\section{Acknowledgements}

First of all, I would like to thank the college leaders who gave me concern. Secondly, I would like to thank my colleague Zhang Yao, Zhang Kaiping, Mao Jianjing and Zhu Jiangbo for their encouragement and help in my thesis writing process; in this, please accept my sincere thanks. Finally, I want to thank my parents, my husband, my daughter; Thank you, my dear family.

\section{References}

[1] Q.D.Meng and L.C.Meng. A Comparative Analysis of the Construction of Teachers in Chinese and American Colleges and Universities [J]. Journal of Hebei Normal University (Educational Science Edition), Vol. 12 (2014) No.8, p.15. (In Chinese)

[2] L.Liu. Xiangzhou District to explore a balanced model of balanced development of education: public school set up to help private schools, Zhuhai Special Zone newspaper, September 24, 2013 the 2 th version. (In Chinese)

[3] D.Zhao. Foreign "Double" Teachers of Enlightenment of Higher Education [J] Hubei University of Economics (Humanities and Social Sciences), Vol. 13 (2016) No.4, p.121. (In Chinese)

[4] X.H.Lin. The Experience and Revelation of the Construction of "Double Teachers" in Foreign Higher Vocational Colleges [J] .Hebei Higher Education Research, Vol. 10 (2011) No.3, p.59. (In Chinese)

[5] X.Wang. A Study on the Construction of "Double Teachers" Teachers in Higher Vocational Education [J]. Journal of Economic Research, Vol. 7 (2014) No.8, p.77. (In Chinese)

[6] Y.Q.Chen. School - enterprise cooperation on the construction of secondary vocational teachers team support research. (MS., Sichuan Normal University, China 2011), p.99. (In Chinese)

[7] G.Z.Feng and Z.Y.Huang. A Study on the Construction of "Double Teachers" Teaching Staff in Higher Vocational Colleges - A Case Study of Guangxi Vocational and Technical College of Mechanical and Electrical Technology [J]. Higher Education Forum, Vol. 6 (2014) No.6, p.8. (In Chinese)

[8] C.W.Li, X.Dong and Y.Jiang. Study and practice of double-qualified teacher team construction based construction faculty at the modern apprenticeship training model [J] Hubei Polytechnic Institute of Industry Technology, Vol. 28 (2015) No.1, p.19. (In Chinese)

[9] E.Wan:The research on the role of enterprises in the construction of "double teacher" teachers in vocational colleges. (MS., Hubei University of Technology, China 2014), p.128. (In Chinese)

[10]L I Yang. University S. Exploration on Teaching Model of Double-Teacher Collaboration for Intellectual Property[J]. Journal of Nanchang Hangkong University, Vol. 2 (2016) No.5, p.112.

[11] Y Zeng, S He and S Zhong. Deficiency and Influencing Factors of "Double Teacher Type" System[J]. Journal of Chengdu University of Traditional Chinese Medicine, Vol. 21 (2015) No.2, p.82. 